\title{
Penerapan Sistem Pemidanaan Terhadap Pelaku Tindak Pidana Penyalahgunaan Narkoba (Studi Kasus di Polda Jateng)
}

\author{
Hera Saputra ${ }^{*}$, Munsyarif Abdul Chalim ${ }^{* *}$
}
* Ditresnarkoba Polda Jateng Ba Subdit I, Mahasiswa Program Magister (S2) Ilmu Hukum Fakultas Hukum UNISSULA Semarang, email : herasaputra1992@gmail.com
* Dosen Fakultas Hukum UNISSULA Semarang

\begin{abstract}
Drugs are short for Psychotropic Drugs and other dangerous Drugs. Besides Drugs, another term introduced especially by the Ministry of Health of the Republic of Indonesia is a drug that is short of Narcotics, Psychotropic and Addictive Substance. Narcotics are substances or drugs derived from plants or non-plants both synthetic and semi-synthetic that can cause decreased or altered consciousness, loss of taste, reduce to eliminate pain, and can cause dependence. Similarly, Psychotropic, Psychotropic is a substance or Law Number 5 Year 1997 About Psychotropic.

Result of research: 1) Misuse of narcotics regulated in Law no. 35 Year 2009 on Narcotics. Article 127 paragraph (1) of Law no. 35 Year 2009, Every Type I Narcotics Abuser for himself shall be punished with imprisonment for a maximum of 4 (four) years; Any Type II Narcotics Abuser for himself shall be subject to a maximum imprisonment of 2 (two) years; and Any Misuse of Narcotics Group III for himself shall be punished with imprisonment for a maximum of 1 (one) year. As for what is meant by Misuse is a person who uses narcotics without right or against the law. 2) Some of the obstacles in the investigation of the crime of misuse or sale of Narcotics are as follows: 1) Lack of Budget, 2) Inadequate Facilities and Infrastructure, 3) Lack of Drug Crime Investigator Personnel, 4) Light Court Decisions, 5) Mutually Binding Each Performer, 6) Dramatic Drugs Technique. Strategy to overcome the abuse of drugs conducted by Polda Central Java through the following ways: . Preventive Efforts a) Pre-empetif, b) Preventive

Keywords: Implementation of Criminal System, Crime, Drug Abuse
\end{abstract}

\begin{abstract}
ABSTRAK
Penelitian ini berjudul Penerapan Sistem Pemidanaan Terhadap Tindak Pidana Penyalah Gunaan Narkoba (Studi Kasus di Polda Jateng). Tujuan Penelitian ini : 1) Untuk mengetahui dan menganalisa sanksi pidana terhadap tentang pelaku penyalahgunaan narkoba di Polda Jateng. 2) Untuk mengetahui dan Menganalisa hambatan-hambatan dan solusi dalam penegakan hukum untuk mengatasi penyalahgunaan narkotika di Polda Jateng.

Hasil Penelitian : 1) Penyalahgunaan narkotika diatur dalam Undang-Undang No. 35 Tahun 2009 tentang Narkotika. Pasal 127 ayat (1) Undang-Undang No. 35 Tahun 2009, Setiap Penyalah Guna Narkotika Golongan I bagi diri sendiri dipidana dengan pidana penjara paling lama 4 (empat) tahun; Setiap Penyalah Guna Narkotika Golongan II bagi diri sendiri dipidana dengan pidana penjara paling lama 2 (dua) tahun; dan Setiap Penyalah Guna Narkotika Golongan III bagi diri sendiri dipidana dengan pidana penjara paling lama 1 (satu) tahun. Adapun yang dimaksud dengan Penyalah Guna adalah orang yang menggunakan narkotika tanpa hak atau melawan hukum. 2) Beberapa hambatan dalam penyidikan tindak pidana penyalahgunaan maupun penjualan Narkotika adalah sebagai berikut : 1)
\end{abstract}


Kurangnya Anggaran, 2) Sarana dan Prasarana yang Kurang Memadai, 3 )Kurangnya Personil Penyidik Tindak Pidana Narkoba, 4) Putusan Pengadilan yang Ringan, 5) Saling Terikatnya Tiap Pelaku, 6) Teknik Peredaran Narkoba yang Berubah-ubah. Strategi penanggulangan penyalahgunan narkoba yang dilakukan Polda Jateng melalui cara sebagai berikut : 1. Upaya Pencegahan a) Pre-empetif, b) Preventif Kata Kunci : Penerapan Sistem Pemidanaan, Tindak Pidana, Penyalahgunaan Narkoba

\section{PENDAHULUAN}

Narkoba adalah singkatan dari Narkotika Psikotropika dan Obat berbahaya lainnya. Selain Narkoba, istilah lain yang diperkenalkan khususnya oleh Kementrian Kesehatan Republik Indonesia adalah NAPZA yang merupakan singkatan dari Narkotika, Psikotropika dan Zat Adiktif. Narkotika adalah zat atau obat yang berasal dari tanaman atau bukan tanaman baik sintetis maupun semi sintetis yang dapat menyebabkan penurunan atau perubahan kesadaran, hilangnya rasa, mengurangi sampai menghilangkan rasa nyeri, dan dapat menimbulkan ketergantungan. ${ }^{1}$ Begitu pula dengan Psikotropika, Psikotropika adalah zat atau Undang-Undang Nomor 5 Tahun 1997 Tentang Psikotropika.

Obat, baik alamiah maupun sintetis bukan narkotika, yang berkasiat psikoaktif melalui pengaruh selektif pada susunan saraf pusat yang menyebabkan perubahan khas pada aktivitas mental dan perilaku. ${ }^{2}$ Di satu sisi narkotika dan psikotropika merupakan obat atau bahan yang bermanfaat di bidang pengobatan, pelayanan kesehatan dan pengembangan ilmu pengetahuan, namun di sisi lain dapat menimbulkan ketergantungan yang sangat merugikan apabila dipergunakan tanpa adanya pengendalian, pengawasan yang ketat dan seksama.

Narkoba atau NAPZA merupakan bahan/zat yang bila masuk ke dalam tubuh akan mempengaruhi tubuh terutama susunan syaraf pusat/otak sehingga jika disalahgunakan akan menyebabkan gangguan fisik, psikis/jiwa dan fungsi sosial. Karena itu Pemerintah memberlakukan Undang-undang untuk penyalahgunaan Narkoba yaitu Undang-undang No.5 tahun 1997 tentang Psikotropika dan Undang-undang No. 35 tahun 2009 tentang Narkotika.

Penentuan penyalahgunaan Narkoba sebagai kejahatan dimulai dari penempatan penyalahgunaan Narkotika dan Psikotropika sebagai kejahatan di dalam undang-undang, yang lazim disebut sebagai kriminalisasi .Tindak pidana penyalahgunaan Narkotika dikriminalisasi melalui perangkat hukum yang mengatur tentang Narkotika yakni Undang-Undang Nomor 35 Tahun 2009 tentang Tindak Pidana Penyalahgunaan Narkotika dalam putusan Nomor 182/Pid.B/2012/PN.BLK.. Undang-undang ini secara tegas mensyaratkan beberapa perbuatan yang dapat dikategorikan sebagai tindak pidana penyalahgunaan Narkoba. Beberapa pasal di dalam undang-undang tentang Narkotika yang dikriminalisasi dijadikan sebagai ketentuan hukum tentang perbuatan yang dilarang dan disertai dengan ancaman pidana bagi barang siapa yang melanggar larangan tersebut.

Kriminalisasi penyalahgunaan Narkotika harus disertai dengan penegakan hukum bagi pelaku melalui sistem pemidanaan yang dianut di Indonesia, salah satunya sistem pemidanaan adalah menerapkan dan menjatuhkan sanksi hukuman bagi pelaku melalui Putusan Hakim yang bertujuan untuk restrorative justice berdasarkan treatment (perawatan) bukan pembalasan seperti paham yang lazim dianut oleh sistem pemidanaan di Indonesia berupa penjatuhan sanksi pidana penjara. Tratment sebagai alternatif pemidanaan bagi pelaku pemakai dan pecandu penyalahgunaan Narkoba sebagai korban peredaran gelap Narkoba sangatlah tepat untuk digunakan dari pada pendekatan retributif dan relatif pada sistem peradilan pidana di Indonesia. Hal ini didasarkan pada pandangan bahwa

\footnotetext{
${ }^{1}$ Partodiharjo, S, 2008. Kenali Narkoba dan Musuhi Penyalahgunaannya Erlangga, Jakarta, hlm 27

${ }^{2}$ Supramono, G. 2001. Hukum Narkotika Indonesia. Djambatan, Jakarta. hlm. 67
} 
penerapan pemidanaan terhadap pelaku tindak pidana Narkoba berdasarkan tujuan tratment lebih diarahkan kepada pelaku sebagai korban bukan kepada perbuatannya sehingga alternatif pemidanaan ini ditujukan untuk memberi tindakan perawatan (treatment) dan perbaikan (rehabilitation) daripada penghukuman.

Penerapan sanksi hukum berupa rehabilitasi bagi pecandu dan pemakai sebagai pelaku penyalahgunaan Narkoba akan mengurangi kelebihan kapasitas lembaga pemasyarakatan di samping dapat mengurangi peredaran gelap Narkoba, untuk itu kerangka yurudis yang telah ada di dalam Undang-Undang Nomor 35 Tahun 2009 seharusnya digunakan oleh hakim dalam memutus pecandu dan pemakai Narkoba yakni Pasal 54 Undang-Undang Nomor 35 Tahun 2009 tentang Narkotika. Pasal 54 Undang-Undang Narkotika menyebutkan bahwa pecandu narkotika dan korban penyalagunaan Narkotika wajib menjalani rehabilitasi medis dan rehabilitasi sosial.

Minimnya putusan Hakim yang memerintahkan rehabilitasi bagi pencandu Narkotika dan ketergantungan Psikotropika disebabkan oleh berbagai faktor yakni: Pertama, Hakim harus melihat kasus per kasus jika akan menerapkan Pasal 54 UU Narkotika. Alasannya, konstruksi hukuman untuk kasus narkotika memang diancam pidana tinggi. Misalnya UU Narkotika mengatur barang siapa memiliki, menyimpan, atau menguasai narkotika golongan I diancam pidana penjara paling lama 12 tahun. Sementara untuk golongan II dan III diancam pidana penjara paling lama tujuh tahun.. Kedua, selain UU Narkotika, Mahkamah Agung (MA) mengeluarkan Surat Edaran Nomor 1 Tahun 2000 tentang Pemidanaan agar setimpal dengan berat dan sifat kejahatannya. Ketiga, persepsi Hakim di dalam memutus perkara Narkoba didasarkan bahwa pemidanaan berupa penjara lebih efektif bila dibandingkan dengan rehabilitasi, di samping itu karakteristik pengedar dan pemakai di dalam UU Narkoba diancam sanksi pidana. ${ }^{3}$

Perumusan masalah dalam penelitian ini : 1) Bagaimanakah sanksi pidana terhadap tentang pelaku penyalahgunaan narkoba di Polda Jateng? 2) Bagaimanakah hambatan-hambatan dan solusi dalam penegakan hukum untuk mengatasi penyalahgunaan narkotika di Polda Jateng?

\section{Metode Penelitian}

Metode pendekatan yang digunakan dalam penelitian ini adalah : Penelitian hukum normatif meliputi penelitian terhadap asas- asas hukum, taraf sinkronisasi hukum ${ }^{4}$ Pendekatan penelitian yang digunakan adalah penelitian yuridis empiris, yaitu pendekatan penelitian yang dapat diamati di dalam kehidupan nyata. Jenis penelitian yang dipergunakan dalam menyelesaikan tesis ini adalah metode penelitian deskriptif, yaitu penelitian yang dilakukan dengan cara meneliti bahan pustaka (data sekunder) atau penelitian hukum perpustakaan ${ }^{5}$.

Jenis data yang digunakan adalah data primer dan sekunder. Data primer adalah data yang diperoleh secara langsung. Data primer dalam penelitian ini mengacu terhadap data atau fakta-fakta dan kasus hukum yang diperoleh langsung melalui penelitian di lapangan termasuk keterangan dari responden yang berhubungan dengan objek penelitian dan praktik yang dapat dilihat serta berhubungan dengan obyek penelitian. Data sekunder adalah data yang diperoleh tidak secara langsung. Data sekunder dalam penelitian ini dilakukan dengan cara studi kepustakaan. Data sekunder ini berguna sebagai landasan teori untuk mendasari penganalisaan pokok-pokok permasalahan yang

\footnotetext{
${ }^{3}$ F. Asya, 2009, Narkotika dan Psikotropika, Jakarta, Asa Mandiri, hlm.15.

${ }^{4}$ Soerjono Soekamto dan Sri Mamudji, 2001. Penelitian Hukum Normatif suatu Tinjauan Singkat Jakarta: Raja Grafindo Persada. hal. 13-14

${ }^{5}$ Ediwarman, Monograf, Metodologi Penelitian Hukum, Medan: Program Pascasarjana Universitas Muhammadiyah Sumatera Utara, Medan, 2010, hal. 24
} 
ada dalam penelitian ini. Data sekunder dalam penelitian ini meliputi :

Bahan hukum primer, yang terdiri dari : Undang-Undang Dasar Negara Republik Indonesia Tahun 1945, KUHP, KUHAP, Undang-Undang Nomor 5 Tahun 1997 Tentang Psikotropika, Undang-Undang Nomor 35 Tahun 2009 Tentang Narkotika, Undang-Undang Nomor 36 Tahun 2009 Tentang Kesehatan; Bahan hukum sekunder, Buku-buku, jurnal, dan dokumen hasil penelitian di bidang hukum khususnya masalah penerapan sistem pemidanaan terhadap pelaku tindak pidana penyalahgunaan narkoba., dan sarana ajar (hand out) tentang tata cara penulisan karya ilmiah. Bahan Hukum Tersier, yang terdiri dari: Kamus Bahasa Indonesia, Kamus Bahasa Inggris, Kamus Hukum, Ensiklopedia.

Metode Pengumpulan Data yang digunakan yaitu Kepustakaan. Penelitian ini menggunakan Library Research (studi kepustakaan) yaitu pengumpulan data yang diperoleh dari sumber-sumber literature, karya ilmiah, peraturan perundang-undangan serta sumber-sumber tertulis lainnya yang berhubungan dengan masalah yang diteliti sebagai landasan teori. Dari penelitian ini data yang diperoleh disebut data sekunder.

Metode analisa data yang digunakan adalah analisa normatif, yaitu dengan memperhatikan faktafakta yang ada dalam praktek lapangan yang kemudian dibandingkan dengan uraian yang didapat dari studi kepustakaan.

\section{HASIL PENELITIAN DAN PEMBAHASAN}

\section{Sanksi Pidana Terhadap Tentang Pelaku Penyalahgunaan Narkoba Di Polda Jateng.}

Dalam sistem hukum di Indonesia, penyalahgunaan narkotika dikualifikasi sebagai kejahatan di bidang narkotika yang diatur dalam UU No. 35 Tahun 2009 tentang Narkotika. Tindak pidana narkotika dipandang sebagai bentuk kejahatan yang menimbulkan akibat serius bagi masa depan bangsa ini, merusak kehidupan dan masa depan terutama generasi muda. Menurut Pasal 127 ayat (1) UU No. 35 Tahun 2009, Setiap Penyalah Guna Narkotika Golongan I bagi diri sendiri dipidana dengan pidana penjara paling lama 4 (empat) tahun; Setiap Penyalah Guna Narkotika Golongan II bagi diri sendiri dipidana dengan pidana penjara paling lama 2 (dua) tahun; dan Setiap Penyalah Guna Narkotika Golongan III bagi diri sendiri dipidana dengan pidana penjara paling lama 1 (satu) tahun. Adapun yang dimaksud dengan Penyalah Guna adalah orang yang menggunakan narkotika tanpa hak atau melawan hukum. ${ }^{6}$

Dari pengertian tersebut dapat dikatakan bahwa Penyalah Guna adalah pengguna. Namun, UU tidak memuat apa yang dimaksud dengan "pengguna narkotika" sebagai subyek (orang), yang banyak ditemukan adalah penggunaan sebagai kata kerja. Apabila dikaitkan dengan pengertian Narkotika sebagaimana disebutkan dalam Pasal 1 angka 1 UU No. 35 Tahun 2009, maka Pengguna Narkotika adalah orang yang menggunakan zat atau obat yang berasal dari tanaman, baik sintesis maupun semi sintesis yang dapat menyebabkan penurunan atau perubahan kesadaran, hilangnya rasa, mengurangi sampai menghilangkan rasa nyeri, dan dapat menimbulkan ketergantungan, yang dibedakan dalam golongan-golongan sebagaimana terlampir dalam Undang-Undang ini. Penggunaan istilah "Pengguna Narkotika" digunakan untuk memudahkan dalam penyebutan bagi orang yang menggunakan narkotika dan untuk membedakan dengan penanam, produsen, penyalur, kurir dan pengedar narkotika. $^{7}$

Keberagaman istilah pengguna narkotika yang menimbulkan ketidakjelasan dalam rumusan UU.

\footnotetext{
${ }^{6}$ Soedjono. D, 1987. Hukum Narkotika Indonesia. Penerbit Alumni. Bandung, hlm. 14

${ }^{7}$ Konvensi PBB tentang Pemberantasan Peredaran Gelap Narkotika dan Psikotropika 1988 sebagaimana diratifikasi dengan UU No. 7 Tahun 1997 menggunakan istilah pemakaian untuk kepentingan sendiri.
} 
Hal itu dapat membingungkan aparat penegak hukum dalam pelaksanaannya. Salah satu permasalahan yang mungkin timbul akibat banyaknya istilah adalah kerancuan pengaturan, dimana dalam Pasal 4 huruf d UU No. 35 Tahun 2009 dikatakan "UU Narkotika bertujuan: Menjamin pengaturan upaya rehabilitasi medis dan sosial bagi penyalahguna dan pecandu narkotika", namun dalam Pasal 54 UU tersebut disebutkan "Pecandu Narkotika dan Korban Penyalahguna Narkotika wajib menjalani rehabilitasi medis dan rehabilitasi sosial". Berdasarkan Pasal 54, hak penyalahguna untuk mendapat rehabilitasi menjadi tidak diakui. ${ }^{8}$

Selanjutnya, penyalahguna yang mendapat jaminan rehabilitasi berdasarkan Pasal 4 UU No. 35 Tahun 2009, namun dalam Pasal 127 penyalahguna dijadikan subyek yang dapat dipidana dan kehilangan hak rehabilitasinya, kecuali dapat dibuktikan atau terbukti sebagai korban narkotika. Padahal pembuktian penyalahguna narkotika merupakan korban narkotika merupakan suatu hal yang sulit, karena harus dilihat dari awal pengguna narkotika menggunakan narkotika. ${ }^{9}$ Di samping itu, perlu dibuktikan bahwa pengguna narkotika ketika menggunakan narkotika dalam kondisi dibujuk, diperdaya, ditipu, dipaksa dan/atau diancam untuk menggunakan narkotika. Banyaknya istilah tersebut dapat membingungkan aparat penegak hukum dalam menerapkan pasal-pasal dalam Undang-Undang No. 35 Tahun 2009. Posisi pecandu narkotika mempunyai posisi sedikit berbeda dengan pelaku tindak pidana lainnya, yakni masalah pecandu narkotika menurut ketentuan undangundang, di satu sisi merupakan pelaku tindak pidana penyalahgunaan narkotika, namun di sisi lain merupakan korban.

Pecandu narkotika menurut undang-undang di satu sisi merupakan pelaku tindak pidana penyalahgunaan narkotika adalah dengan adanya ketentuan undang-undang narkotika yang mengatur mengenai pidana penjara yang diberikan kepada para pelaku penyalahgunaan narkotika. Kemudian, di sisi lainnya dapat dikatakan pecandu narkotika tersebut merupakan korban adalah ditunjukkan dengan adanya ketentuan bahwa terhadap pecandu narkotika dapat dijatuhi vonis rehabilitasi. ${ }^{10} \mathrm{Hal}$ ini berarti undang-undang di satu sisi masih menganggap pecandu narkotika sebagai pelaku tindak pidana, dan di sisi lain merupakan korban dari penyalahgunaan narkotika yang dilakukannya. Tinjauan victimology, mengklasifikasikan pecandu narkotika sebagai "self victimizing victims" yakni korban dari kejahatan yang dilakukannya sendiri. oleh sebab itu maka, yang paling tepat dalam hakim menjatuhkan vonis dalam perkara pecandu narkotika adalah dengan menjatuhkan vonis rehabilitasi. Sebab pecandu narkotika pada hakikatnya merupakan korban dari suatu kejahatan yang perlu mendapatkan pengobatan dan/atau perawatan, dan oleh karena ia merupakan pihak yang juga mengalami kerugian dari suatu kejahatan yakni kejahatan penyalahgunaan narkotika. ${ }^{11}$

Walaupun penanam, produsen, penyalur, kurir dan pengedar narkotika kadang juga menggunakan narkotika, namun dalam tulisan ini yang dimaksud pengguna narkotika adalah orang yang menggunakan narkotika untuk dirinya sendiri, bukan penanam, produsen, penyalur, kurir dan pengedar narkotika. Jika dikaitkan dengan orang yang menggunakan narkotika, dalam UU No. 35 Tahun 2009 dapat ditemukan berbagai istilah, yaitu:

a. Pecandu Narkotika adalah orang yang menggunakan atau menyalahgunakan Narkotika dan dalam

\footnotetext{
${ }^{8}$ Muhammad Taufik Makarao, 2003. Tindak Pidana Narkotika. Ghalia Indonesia. Jakarta, hlm 43

${ }^{9}$ Hari Sasangka, 2003. Narkotika dan Psikotropika dalam Hukum Pidana. Mandar Maju. Bandung.hlm. 42

${ }^{10}$ Lydia Harlina Martono \& Satya Joewana, 2006. Membantu Pemulihan Pecandu Narkoba dan Keluarganya, Balai Pustaka, Jakarta.hlm. 72

${ }^{11}$ Romli Atmasasmita, 1996. Sistem Peradilan Pidana Perspektif Eksistensialisme dan Abolisionisme. Bandung, Percetakan Binacipta.hlm. 51
} 
keadaan ketergantungan pada Narkotika, ${ }^{12}$ baik secara fisik maupun psikis. ${ }^{13}$

b. Penyalah Guna adalah orang yang menggunakan Narkotika tanpa hak atau melawan hukum. ${ }^{14}$

c. Korban penyalahgunaan Narkotika adalah seseorang yang tidak sengaja menggunakan Narkotika karena dibujuk, diperdaya, ditipu, dipaksa, dan/ atau diancam untuk menggunakan Narkotika. ${ }^{15}$

d. Mantan Pecandu Narkotika adalah orang yang telah sembuh dari ketergantungan terhadap narkotika secara fisik maupun psikis. ${ }^{16}$

Keberagaman istilah pengguna narkotika tersebut menimbulkan ketidakjelasan dalam rumusan

UU. Hal itu dapat membingungkan aparat penegak hukum dalam pelaksanaannya. Salah satu permasalahan yang mungkin timbul akibat banyaknya istilah adalah kerancuan pengaturan, dimana dalam Pasal 4 huruf d UU No. 35 Tahun 2009 dikatakan "UU Narkotika bertujuan: Menjamin pengaturan upaya rehabilitasi medis dan sosial bagi penyalahguna dan pecandu narkotika", namun dalam Pasal 54 UU tersebut disebutkan "Pecandu Narkotika dan Korban Penyalahguna Narkotika wajib menjalani rehabilitasi medis dan rehabilitasi sosial". Berdasarkan Pasal 54, hak penyalahguna untuk mendapat rehabilitasi menjadi tidak diakui.

Dalam hal pemberantasan sesuai dengan hukum yang berlaku penyidik di Direktorat Reserse Narkoba Polda Jateng telah melakukan upaya dari mulai kegiatan penyelidikan yang diawali dengan adanya Laporan Polisi dari masyarakat, adapun rangkaian kegiatan penyelidikan sesuai dengan keterangan AKP Subhan salah seorang Kepala Unit di Sub Direktorat Reserse Narkoba adalah sebagai berikut :

1. Pengolahan TKP;

a) mencari dan mengumpulkan keterangan, petunjuk, barang bukti, identitas tersangka, dan Saksi/korban untuk kepentingan penyelidikan selanjutnya;

b) mencari hubungan antara saksi/korban, tersangka, dan barang bukti; dan

c) memperoleh gambaran modus operandi tindak pidana yang terjadi;

2. Pengamatan (observasi);

a) melakukan pengawasan terhadap objek, tempat, dan lingkungan tertentu untuk mendapatkan informasi-informasi yang dibutuhkan; dan

b) mendapatkan kejelasan atau melengkapi informasi yang sudah ada berdasarkan pengetahuan dan gagasan yang diketahui sebelumnya;

3. wawancara (interview);

a) mendapatkan keterangan dari pihak-pihak tertentu melalui teknik wawancara secara tertutup maupun terbuka; dan

b) mendapatkan kejelasan tindak pidana yang terjadi dengan cara mencari jawaban atas pertanyaan siapa, apa, dimana, dengan apa, mengapa, bagaimana, dan bilamana;

4. Pembuntutan (surveillance);

a) mengikuti seseorang yang diduga sebagai pelaku tindak pidana atau orang lain yang dapat mengarahkan kepada pelaku tindak pidana;

b) mencari tahu aktivitas, kebiasaan, lingkungan, atau jaringan pelaku tindak pidana; dan

c) mengikuti distribusi barang atau tempat penyimpanan barang hasil kejahatan;

\footnotetext{
12 Ketergantungan Narkotika adalah kondisi yang ditandai oleh dorongan untuk menggunakan Narkotika secara terusmenerus dengan takaran yang meningkat agar menghasilkan efek yang sama dan apabila penggunaannya dikurangi dan/atau dihentikan secara tiba-tiba, menimbulkan gejala fisik dan psikis yang khas (Pasal 1 angka 14).

${ }^{13}$ Pasal 1 angka 13 UU No. 35 Tahun 2009.

${ }^{14}$ Pasal 1 angka 15 UU No. 35 Tahun 2009.

${ }^{15}$ Penjelasan Pasal 54 UU No. 35 Tahun 2009.

${ }^{16}$ Penjelasan Pasal 58 UU No. 35 Tahun 2009.
} 


\section{Penyamaran (under cover);}

a) menyusup ke dalam lingkungan tertentu tanpa diketahui identitasnya untuk memperoleh bahan keterangan atau informasi;

b) menyatu dengan kelompok tertentu untuk memperoleh peran dari kelompok tersebut, guna mengetahui aktivitas para pelaku tindak pidana; dan

c) khusus kasus peredaran narkoba, dapat digunakan teknik penyamaran sebagai calon pembeli (undercover buy), penyamaran untuk dapat melibatkan diri dalam distribusi narkoba sampai tempat tertentu (controlled delivery), penyamaran disertai penindakan/pemberantasan (raid planning execution);

6. Pelacakan (tracking);

a) mencari dan mengikuti keberadaan pelaku tindak pidana dengan menggunakan teknologi informasi;

b) melakukan pelacakan melalui kerja sama dengan Interpol, kementerian/ lembaga/ badan/komisi/instansi terkait; dan

c) melakukan pelacakan aliran dana yang diduga dari hasil kejahatan;

7. Penelitian dan Analisis Dokumen.

Penelitian dan analisis dokumen, yang dilakukan terhadap kasus-kasus tertentu dengan cara:

a) mengkompulir dokumen yang diduga ada kaitan dengan tindak pidana penyalahgunaan narkotika seperti transaksi keuangan melalui perbankan dan data komunikasi melalui telepon seluler.

b) meneliti dan menganalisis dokumen yang diperoleh guna menyusun anatomi perkara tindak pidana serta modus operandinya.

Kegiatan penyelidikan merupakan bagian atau salah satu cara dalam melakukan penyidikan untuk:

1. menentukan suatu peristiwa yang terjadi merupakan tindak pidana atau bukan;

2. membuat terang suatu perkara sampai dengan menentukan pelakunya; dan

3. dijadikan sebagai dasar melakukan upaya paksa

\section{Hambatan-Hambatan Dan Solusi Dalam Penegakan Hukum Untuk Mengatasi Penyalahgunaan Narkotika Di Polda Jateng}

Untuk dapat memulai penyidikan tindak pidana narkoba harus terdapat fakta-fakta yang lengkap, bukti permulaan yang cukup dan terdeteksi/teridentifikasinya tersangka. Beberapa hambatan dalam penyidikan tindak pidana penyalahgunaan maupun penjualan Narkotika adalah sebagai berikut :

1. Kurangnya Anggaran

2. Sarana dan Prasarana yang Kurang Memadai

3. Kurangnya Personil Penyidik Tindak Pidana Narkoba

4. Putusan Pengadilan yang Ringan

5. Saling Terikatnya Tiap Pelaku

6. Teknik Peredaran Narkoba yang Berubah-ubah

Strategi penanggulangan penyalahgunan narkoba yang dilakukan Polda Jateng melalui cara sebagai berikut :

1. Pre-empetif

2. Preventif 


\section{KESIMPULAN}

1. Penyalahgunaan narkotika diatur dalam Undang-Undang No. 35 Tahun 2009 tentang Narkotika. Pasal 127 ayat (1) Undang-Undang No. 35 Tahun 2009, Setiap Penyalah Guna Narkotika Golongan I bagi diri sendiri dipidana dengan pidana penjara paling lama 4 (empat) tahun; Setiap Penyalah Guna Narkotika Golongan II bagi diri sendiri dipidana dengan pidana penjara paling lama 2 (dua) tahun; dan Setiap Penyalah Guna Narkotika Golongan III bagi diri sendiri dipidana dengan pidana penjara paling lama 1 (satu) tahun. Adapun yang dimaksud dengan Penyalah Guna adalah orang yang menggunakan narkotika tanpa hak atau melawan hukum.

2. Beberapa hambatan dalam penyidikan tindak pidana penyalahgunaan maupun penjualan Narkotika adalah sebagai berikut : Kurangnya Anggaran, Sarana dan Prasarana yang Kurang Memadai, Kurangnya Personil Penyidik Tindak Pidana Narkoba, Putusan Pengadilan yang Ringan, Saling Terikatnya Tiap Pelaku, dan Teknik Peredaran Narkoba yang Berubah-ubah

Strategi penanggulangan penyalahgunan narkoba yang dilakukan Polda Jateng melalui cara sebagai berikut : Preempetif dan Preventif

\section{DAFTAR PUSTAKA}

Ediwarman, 2010. Monograf, Metodologi Penelitian Hukum, Medan: Program Pascasarjana Universitas Muhammadiyah Sumatera Utara, Medan.

F. Asya, 2009. Narkotika dan Psikotropika, Jakarta, Asa Mandiri.

Hari Sasangka, 2003. Narkotika dan Psikotropika dalam Hukum Pidana. Mandar Maju. Bandung.

Lydia Harlina Martono \& Satya Joewana, 2006. Membantu Pemulihan Pecandu Narkoba dan Keluarganya, Balai Pustaka, Jakarta.

Muhammad Taufik Makarao, 2003. Tindak Pidana Narkotika. Ghalia Indonesia. Jakarta.

Partodiharjo, S, 2008. Kenali Narkoba dan Musuhi Penyalahgunaannya Erlangga, Jakarta.

Romli Atmasasmita, 1996. Sistem Peradilan Pidana Perspektif Eksistensialisme dan Abolisionisme. Bandung, Percetakan Binacipta.

Soedjono. D, 1987. Hukum Narkotika Indonesia. Penerbit Alumni. Bandung.

Soerjono Soekamto dan Sri Mamudji, 2001. Penelitian Hukum Normatif suatu Tinjauan Singkat Jakarta: Raja Grafindo Persada.

Supramono, G. 2001. Hukum Narkotika Indonesia. Djambatan, Jakarta.

Kitab Undang-Undang Hukum Pidana.

Kitab Undang-Undng Hukum Acara Pidana.

Undang-Undang Nomor 5 Tahun 1997 Tentang Psikotropika.

Undang-Undang Nomor 35 Tahun 2009 Tentang Narkotika.

Undang-Undang Nomor 36 Tahun 2009 Tentang Kesehatan.

Konvensi PBB tentang Pemberantasan Peredaran Gelap Narkotika dan Psikotropika 1988. 